Article

\title{
Enhancement of Methane Production in Thermophilic Anaerobic Co-Digestion of Exhausted Sugar Beet Pulp and Pig Manure
}

\author{
Xiomara Gómez-Quiroga $₫$, Kaoutar Aboudi, Carlos José Álvarez-Gallego and \\ Luis Isidoro Romero-García *D \\ Department of Chemical Engineering and Food Technology, Faculty of Sciences (Wine and Agri-Food Research \\ Institute-IVAGRO and International Campus of Excellence-ceiA3), University of Cádiz, Republic Saharawi \\ Avenue, P.O. Box No. 40, 11510 Puerto Real (Cádiz), Spain; xiomara.gomez@uca.es (X.G.-Q.); \\ kaoutar.aboudi@uca.es (K.A.); carlosjose.alvarez@uca.es (C.J.Á.-G.) \\ * Correspondence: luisisidoro.romero@uca.es; Tel.: +34-956-016-379
}

Received: 29 March 2019; Accepted: 26 April 2019; Published: 29 April 2019

check for updates

\begin{abstract}
In this paper, the viability of thermophilic anaerobic co-digestion of exhausted sugar beet pulp (ESBP) and pig manure (PM) was evaluated. The effect of the proportion of ESBP on biogas production was investigated by using a series of lab-scale batch assays, in duplicates. The following five ESBP:PM mixture ratios were studied: 0:100, 10:90, 25:75, 50:50, and 100:0. The highest cumulative methane production (212.4 $\mathrm{mL} \mathrm{CH}_{4} / \mathrm{g} \mathrm{VS}_{\text {added }}$ ) was reached for the mixture 25:75. The experimental results showed that the increase in the proportion of ESBP in the mixture led to the distortion of the process, due to acidification by the volatile fatty acids generated. Acetic acid was the predominant acid in all the cases, representing more than $78 \%$ of the total acidity. Moreover, the results obtained by operating at thermophilic temperatures have been compared with those obtained in a previous study conducted at mesophilic temperatures. The results have shown that in the individual digestion of ESBP, the activity of acetoclastic methanogens was affected in both temperatures, but especially in thermophilic conditions. Thus, the methane produced in the individual thermophilic digestion of ESBP came almost entirely from the activity of hydrogen-utilizing methanogenic archaea.
\end{abstract}

Keywords: exhausted sugar beet pulp; pig manure; anaerobic co-digestion; thermophilic; lignocellulosic waste

\section{Introduction}

The main component of agro-industrial waste is lignocellulose, which is constituted by three fractions-lignin, hemicellulose and cellulose [1]. Lignocellulosic biomass can be converted into different products, including biofuels and fine chemicals with a high added-value, and can also be used as a cheap substrate source in microbial fermentation and enzyme production [2].

An interesting by-product generated in the process of sugar extraction from sugar beet (Beta vulgaris), is the exhausted sugar beet pulp (ESBP), which has the following composition-24\%-32\% of hemicellulose, $22 \%-30 \%$ of cellulose, $3 \%-4 \%$ of lignin, and $24 \%-32 \%$ of pectin [3]. Therefore, ESBP is a suitable substrate for biogas production, through the anaerobic digestion process (AD) [4-6]. The use of biogas produced from ESBP could generate economic and environmental benefits for energy-intensive consumers, such as sugar beet industries and, hence, contribute to the circular economy.

$\mathrm{AD}$ is a mature, highly efficient, and economically viable technology for transforming organic wastes into methane [7-9]. The process occurs under anaerobic conditions, requiring considerably less energy with respect to the aerobic treatment processes [10]. 
Agro-industrial by-products could release, depending on their nature and origin, toxic or inhibitory compounds for microorganisms, such as ammonia, sulphides, heavy metals, long chain fatty acids (LCFAs), and other organic compounds. The intensification of the microorganisms activity in the system, especially the increase of their hydrolytic ability, could be counterproductive if the breakdown of the lignocellulosic material resulted in the release of intermediate inhibitory compounds. The accumulation of these compounds would lead to the destabilization of the AD process [11]. Therefore, in order to improve the efficiency and stability of the AD process, a deep knowledge of the critical process parameters, affecting the different microbial groups is required [12,13].

According to the literature, operations in thermophilic temperature ranges $\left(50-60{ }^{\circ} \mathrm{C}\right)$ lead to a higher biogas production than in mesophilic range $\left(30-40^{\circ} \mathrm{C}\right)$, but compromises the stability of the process [14,15].

However, the decomposition of agro-industrial by-products could present limitations due to the presence of non-biodegradable lignocellulose and the deficit in the nitrogen source, with respect to the high content in organic matter $[1,16]$.

Aboudi et al. [11] have reported that thermophilic or hyperthermophilic acidogenic anaerobic digestion of ESBP led to the accumulation of LCFAs, such as palmitate and lignocerate. The use of the effluents from these reactors for the feeding of two subsequent mesophilic reactors led to the inhibition of methanogenic archaea population. LCFAs are considered inhibitory compounds for the AD process, especially for methanogenic microorganisms [17].

With respect to the deficit of nitrogen in ESBP, several authors $[18,19]$ have shown that the anaerobic co-digestion (AcoD) of ESBP with animal manure, solves this problem. Thus, animal manure supplies the necessary nutrients, but it also provides alkalinity and specific microorganisms, originating from the digestive tract of animals, which are capable of degrading vegetal fibers [20,21]. Therefore, animal manure improves, both, the biodegradability of the lignocellulosic material and the stability of the AD process. Aboudi et al. [22], have studied the AcoD of ESBP with pig manure (PM) in continuous stirred tank reactor (CSTR) reactors operating in the mesophilic range of temperature. Other authors [23-25] have studied the AcoD of different agricultural wastes with animal manure and have shown that co-digestion improves the anaerobic process and waste digestibility.

The main objective of this study was to determine the optimal mixture ratio of ESBP and PM for the thermophilic anaerobic co-digestion of both wastes. In addition, the effect of temperature on the process performance was studied by performing a comparison with the previous results reported in the literature, for mesophilic AcoD, using similar wastes.

\section{Materials and Methods}

\subsection{Substrate and Inoculum}

The ESBP samples came from a high-size sugar beet factory (AB Sugar ${ }^{\mathrm{TM}}$ ) located in Jerez de la Frontera (Cádiz, Spain). The ESBP samples have a very high solid content (TS range $80 \%-90 \%$ ) that facilitated their conservation. The samples of PM were collected in a local farm placed in San José del Valle (Cádiz, Spain). The farm did not have any device for the separation of urine and feces. The samples were frozen at $-20^{\circ} \mathrm{C}$, unfrozen, and stored at $4{ }^{\circ} \mathrm{C}$, when they were close to being used.

The mixtures of ESBP and PM were prepared, considering the proportions of each waste, on a wet weight basis, and a total solid content of $8 \%$ was maintained. ESBP samples were previously rehydrated for $24 \mathrm{~h}$, in deionized water [11]. ESBP is highly hygroscopic and, hence, the total solids percentage must be limited to $8 \%$, to avoid rheological problems into the reactors. Indeed, previous studies determined that the increase in solids content impeded an adequate mixing in the reactor, due to the high water holding capacity of ESBP [26-30]. The following mixtures of ESBP:PM (weight basis) were studied: 0:100, 10:90, 25:75, 50:50, and 100:0.

The inoculum used in the experiments came from a lab-scale semi-continuous reactor for the AcoD of ESBP and PM. The reactor has been working in the thermophilic temperature range $\left(55^{\circ} \mathrm{C}\right)$ 
and was fed with an ESBP:PM mixture of (10:90), also with a total solids content of $8 \%$. When the inoculum samples were taken, the reactor was operating in stable conditions with a hydraulic retention time of 30 days, a methane yield around $105-110 \mathrm{~mL} \mathrm{CH} / \mathrm{gVS}_{\text {added, }}$, and a productivity of $0.22-0.24 \mathrm{LCH}_{4} / \mathrm{L}_{\text {reactor}}$.day. The use of an adapted inoculum to carry out the $\mathrm{AD}$ assays guaranteed an efficient start-up of the process [30]. The inoculum to substrate ratio was at 1:1 (volume basis).

The physicochemical characteristics of the substrates and the inoculum are shown in Table 1.

Table 1. Physicochemical characteristics of the substrates and inoculum.

\begin{tabular}{ccccc}
\hline Component & Units & ESBP & PM & Inoculum \\
\hline $\mathrm{pH}$ & - & $6.22 \pm 0.03$ & $8.26 \pm 0.10$ & $7.96 \pm 0.08$ \\
$\mathrm{TS}$ & $\mathrm{g} / \mathrm{kg}$ & $857.7 \pm 0.04$ & $276.3 \pm 0.27$ & $55.67 \pm 0.15$ \\
$\mathrm{VS}$ & $\mathrm{g} / \mathrm{kg}$ & $758.6 \pm 0.06$ & $156.8 \pm 0.30$ & $28.43 \pm 0.11$ \\
$\mathrm{sCOD}$ & $\mathrm{g} / \mathrm{kg}$ & $21.0 \pm 0.42$ & $7.0 \pm 0.28$ & $3.4 \pm 0.39$ \\
TVFA & $\mathrm{g} / \mathrm{kg}$ & $1.99 \pm 0.31$ & $1.2 \pm 0.02$ & $0.72 \pm 0.10$ \\
Alkalinity & $\mathrm{g} / \mathrm{kg}$ & $2.19 \pm 0.10$ & $33.1 \pm 0.50$ & $11.8 \pm 0.77$ \\
C/N ratio & - & $37.4 \pm 0.22$ & $3.03 \pm 0.27$ & - \\
Pectins & $\%$ & 55.54 & - & 69.31 \\
Hemicellulose & $\%$ & 22.52 & - & 11.29 \\
Cellulose & $\%$ & 21.14 & - & 11.90 \\
Lignin & $\%$ & 3.50 & - & 5.61 \\
\hline
\end{tabular}

All results were calculated in a wet basis. ESBP: Exhausted Sugar Beet Pulp, PM: Pig Manure, TS: Total Solids, VS: Volatile Solids, sCOD: Soluble Chemical Oxygen Demand, TVFA: Total Volatile Fatty Acid, -: No unit/Not analyzed.

\subsection{Experimental Design}

A series of 10 stainless steel reactors with a working volume of $1.7 \mathrm{~L}$ were operated in batch mode. Each reactor had independent devices for heating and stirring. The biogas production was continuously measured using a MilliGas counter (Ritter ${ }^{\circledR}$ ) and a series of specific infrared on-line sensors for $\mathrm{CH}_{4}$ and $\mathrm{H}_{2}$ determinations (Calibrated and certified by Bluesens ${ }^{\circledR}$ ). Figure 1 shows an illustration of the equipment used for the biogas measurement and the characterization.

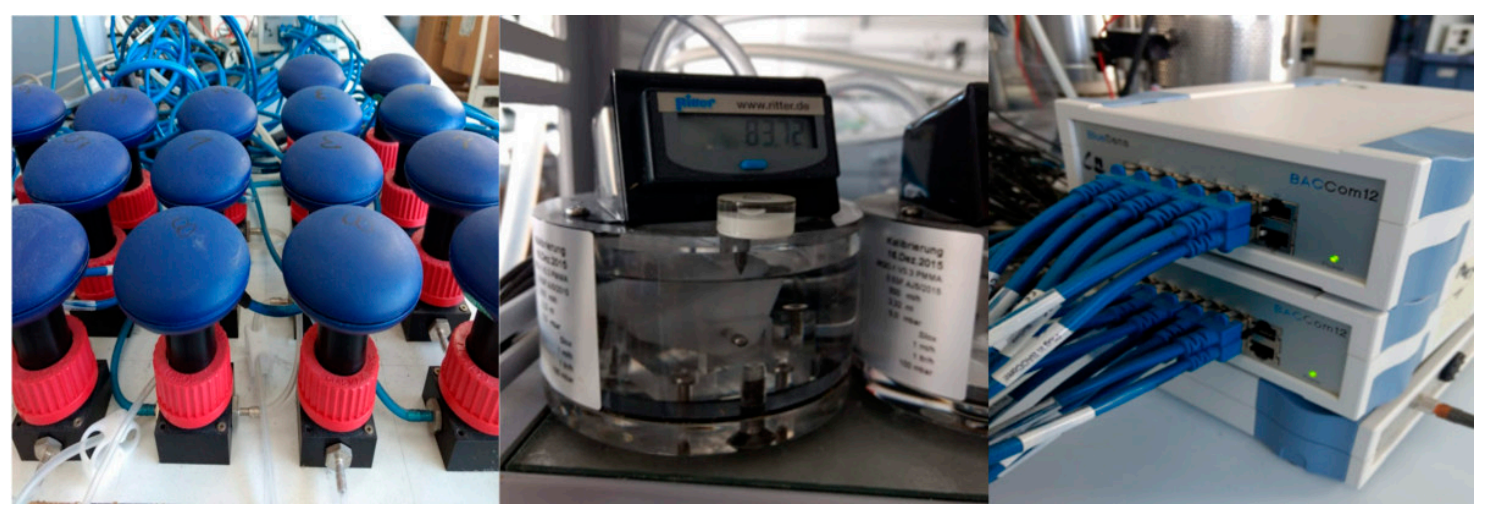

Figure 1. Equipment used for the biogas measurement and characterization. From left to right-infrared on-line sensors, the MilliGas counter, and the data interface module.

Subsequently, the reactors were hermetically sealed and purged with $\mathrm{N}_{2}$ to remove the residual $\mathrm{O}_{2}$. The temperature was continuously measured by an inner sensor and was maintained at $55^{\circ} \mathrm{C}$. The mixing was performed by paddles $(20 \mathrm{rpm})$.

\subsection{Analytical Methods}

All analytical determinations were performed according to the Standard Methods [31]. The following reference methods were used-Total Solids (TS) by 2540B, Volatile Solids (VS) by 2540E, total Chemical Oxygen Demand (tCOD), and soluble Chemical Oxygen Demand (sCOD) by 5220C, 
Dissolved Organic Carbon (DOC) by 5310B, using a carbon/nitrogen analyzer (Analytic-Jena multi N/C 3100 with chemiluminescence detector, Endress+Hauser Company ${ }^{\circledR}$, Waldheim, Germany), alkalinity by $2320 \mathrm{~B}$ and $\mathrm{pH}$ by $4500 \mathrm{H}^{+}$. In addition, the concentration of the main individual volatile fatty acids (VFAs), from C2 to C7, were measured by using a gas chromatograph GC-2010 (Shimadzu Corporation ${ }^{\circledR}$, Kyoto, Japan) with flame ionization detector and a Nukol ${ }^{\circledR}$ capillary with a diameter of $0.25 \mathrm{~mm}$ and $30 \mathrm{~m}$ of length column (Merck KGaA ${ }^{\circledR}$, Darmstadt, Germany). The hydrogen was used as carrier gas with a flow of $50 \mathrm{~mL} / \mathrm{min}$ and $75.5 \mathrm{kPa}$; synthetic air $(400 \mathrm{~mL} / \mathrm{min}$ and $50 \mathrm{kPa})$ and hydrogen $(40 \mathrm{~mL} / \mathrm{min}$ and $60 \mathrm{kPa})$ were used for the flame ignition, and nitrogen $(30 \mathrm{~mL} / \mathrm{min}$ and $75 \mathrm{kPa})$ was used as the make-up gas. All the gases were provided by Abello-Linde ${ }^{\circledR}$ (Barcelona, Spain).

The $\mathrm{pH}$ was measured daily and directly into the reactor. The remaining parameters were analyzed three times per week. Prior to the analysis of SCOD, DOC, and VFA, the samples were centrifuged in a Consul-21 Ortoalresa ${ }^{\circledR}$ equipment (Madrid, Spain) at 3220 $\times g$ during $15 \mathrm{~min}$ and filtered with a $0.47 \mu \mathrm{m}$ glass microfiber filter (ref. GF52047, Hahnemühle ${ }^{\circledR}$, Dassel, Germany). For the analysis of VFAs, an additional filtration was carried out through a $0.22 \mu \mathrm{m}$ PTFE filter manufactured by Rephile Bioscience ${ }^{\circledR}$ (Shanghai, China) [32].

To determine the lignocellulosic fractions of the samples (cellulose, hemicellulose, and lignin), the FIBERTEC ${ }^{\mathrm{TM}} 8000$ equipment (FOSS ${ }^{\circledR}$, Hilleroed, Denmark) was used by applying the Van Soest method [33].

\subsection{Indirect Parameters}

Fdez-Güelfo et al. [8] have proposed a series of indirect parameters that can be used to analyze the performance of the different stages of the anaerobic digestion process and to determine the rate-limiting stage for specific operating conditions.

These parameters include the Dissolved Acid Carbon (DAC) and the Acidogenic Substrate as Carbon (ASC). The DAC is the carbon contained in the volatile fatty acids (C2 to C7) present in the medium. An increase in DAC is related to a failure in the methanogenic stage. The ASC corresponds to the difference (expressed in carbon units) between the Dissolved Organic Carbon (analytical value of DOC) and the DAC (calculated value). The ASC represents the solubilized organic carbon that has not been transformed into acids, and an increase in this parameter could be interpreted as a distortion of the acidogenic stage.

Angeriz-Campoy et al. [34] have used the indirect parameter ASC and have corroborated that the failure in the AcoD of organic fraction of municipal solid waste and sewage sludge, was due to a distortion in the hydrolytic phase. Aboudi et al. [35] have used the indirect parameters to analyze the AcoD of exhausted sugar beet pulp and cow manure, in the mesophilic range of temperature as well.

\section{Results and Discussion}

\subsection{Waste Characteristics}

As can be seen in the Table 1, the ESBP is a lignocellulosic material with a very high organic matter content (high values of VS y COD). However, the alkalinity of ESBP is relatively low with respect to its organic content. Therefore, a mixture with PM could be favorable, since PM has a 12 times higher alkalinity. In addition, the C/N ratio indicates that ESBP is deficient in nitrogen and, hence, co-digestion with PM might adjust the nutrient content.

\subsection{Process Stability}

The $\mathrm{pH}$ is the result of the acid-base equilibrium in the process and, therefore, is related to the production of VFAs and alkalinity. The $\mathrm{pH}$ is considered a key parameter in the stability of the anaerobic digestion process, since a low $\mathrm{pH}$ value implies that the organic acids are mainly in their undissociated form, which is the most inhibitory for the anaerobic microbiota [19]. In fact, if the pKa of the acetic acid ( $\mathrm{pKa}=4.76$ at $25^{\circ} \mathrm{C}$ ) is considered, approximately $15 \%$ of the acid would be 
present in its undissociated form at $\mathrm{pH}=5.5$, while at $\mathrm{pH}=4.76$ the undissociated form could reach a $50 \%$. The low alkalinity of the lignocellulosic waste leads to an eventual acidification of the system, because VFAs accumulation significantly diminishes the buffer capacity, affecting the growth rate of the microorganisms capable of transforming the organic matter into biogas [36].

The buffer capacity of the system could be increased by the addition of strong bases or carbonate salts, even though the $\mathrm{CO}_{2}$ percentage in biogas could be affected [37]. Figure 2 shows the $\mathrm{pH}$ and the acidity/alkalinity ratio evolution in the experiments.

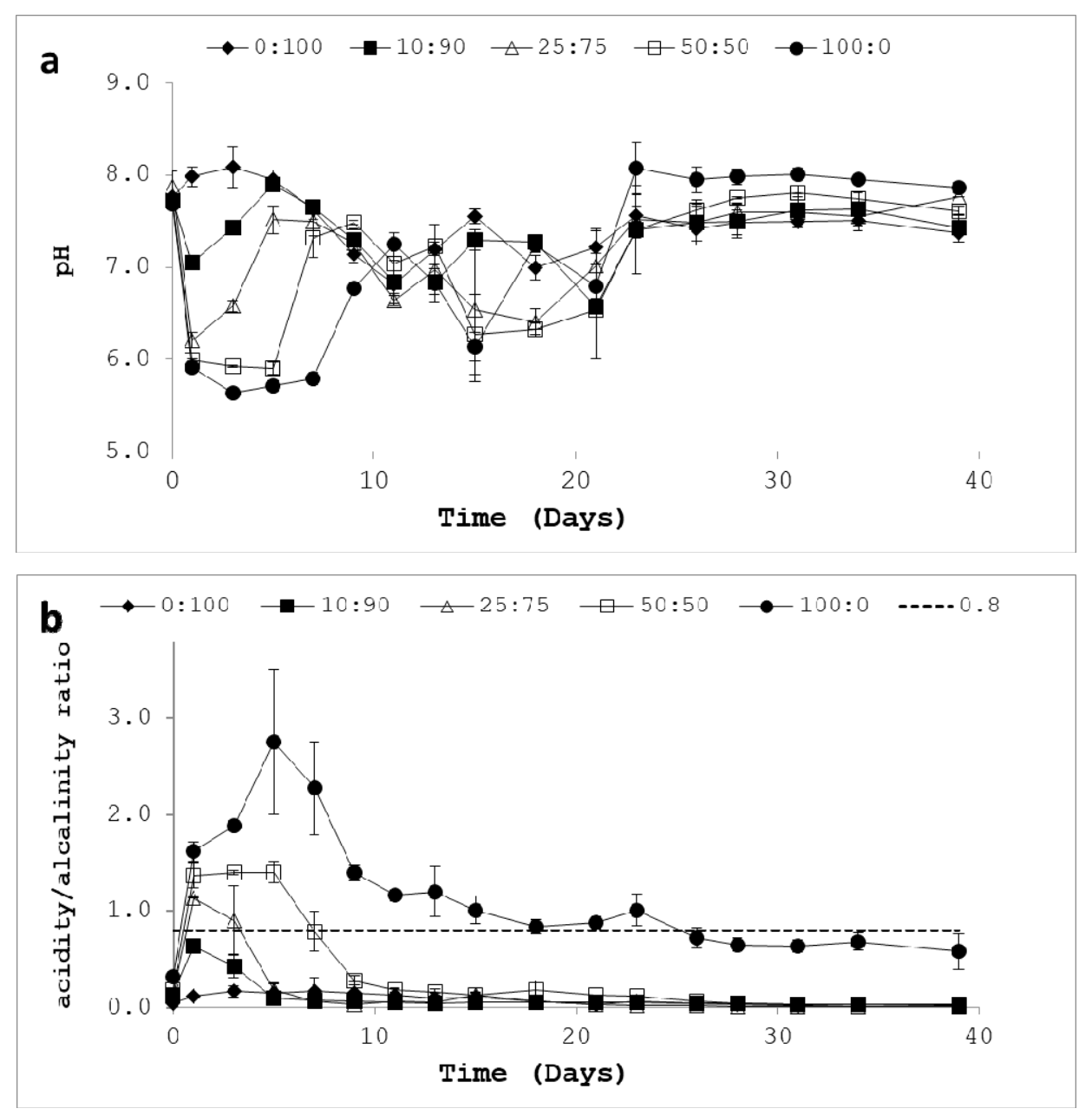

Figure 2. pH evolution (a) and acidity/alkalinity ratio evolution (b) in all ESBP:PM ratios.

In this work, during the first days of operation, the $\mathrm{pH}$ diminished below the required range, especially in the reactors with high content in ESBP, as can be seen in Figure 2a. The daily correction of $\mathrm{pH}$ with potassium carbonate, permitted all reactors to operate in the appropriate $\mathrm{pH}$ range, within a few days [38]. However, for reactors with the mixture ratios 0:100, 10:90, and 25:75, the $\mathrm{pH}$ was stabilized rapidly and the required additions of the alkaline reagent were very low. Specifically, the additions of potassium carbonate were 3, 5, and $8 \mathrm{~g}$ for the tests 0:100, 10:90, and 25:75, respectively, whereas for reactors 50:50 and 100:0 were necessary 12 and $46 \mathrm{~g}$, respectively. To the end of the process, the $\mathrm{pH}$ in all reactors were in the required range.

The acidity/alkalinity ratio has been used as an indicator of acidification problems in anaerobic reactors. In the literature, three different ranges have been identified for this parameter-values below 0.4 indicate an optimal process performance; values between 0.4 and 0.8 are evidence of the beginning of process distortion and, finally, values higher than 0.8 indicate that a total or a partial inhibition of the methanogenic activity occurred [39-41]. 
Figure $2 \mathrm{~b}$ shows that for the mixture $0: 100$, the ratio was in the optimum range, throughout the whole assay, while for the mixture 10:90, this ratio was over 0.4 for the first days, and then rapidly reached the optimum range. However, for the mixtures 25:75 and 50:50, the acidity/alkalinity ratio initially exceeded 0.8 and a longer period was required (which increased with an in increase in the ESBP content), to reach the optimum level. For the reactor containing only ESBP (100:0), the ratio remained above 0.8 for most of the test, and only reached values between 0.4 and 0.8 at the end of the assay.

Therefore, according to the acidity/alkalinity ratio, the increase in the percentage of animal manure (PM) in the mixture had a beneficial effect on the stability of the AcoD of ESBP and PM.

Figure 3a shows the evolution of the total volatile fatty acidity (TVFA) in all tests. The initial acidification was due to the rapid release of VFAs and it seemed to be a characteristic of the ESBP, as a substrate in the AD process [4]. Indeed, as the content of ESBP in the mixtures increased, the release of VFAs was more abrupt, reaching higher maximum concentrations of TVFA. Moreover, the time needed to reduce the TVFA concentration from the maximum value was longer for reactors with a high fraction of ESBP in the mixture, showing a decoupling between the acidogenic and acetoclastic-methanogenic activities. In the case of the mixture 100:0, the higher values of VFAs seemed to have inhibited the activity of the acetoclastic-methanogenic archaea population, since the VFAs had not degraded over the 40 days of operation.

Figure $3 \mathrm{~b}$ shows the main individual VFAs observed in the different tests. Acetic (HAc), propionic $(\mathrm{HPr})$, and butyric $(\mathrm{HBu})$ acids together represented more than $80 \%-90 \%$ of the TVFA (when the maximum of TVFA was reached). Acetic acid was the predominant in all the cases, representing more than $78 \%$ of TVFA. It could be observed that an increase in the concentrations of the three main organic acids occurred when the content in ESBP was increased in the mixtures. In the test 100:0, the maximum concentration of acetic acid was $19.5 \mathrm{~g} / \mathrm{L}$, whereas the concentrations of propionic and butyric acids were 1.4 and $2.5 \mathrm{~g} / \mathrm{L}$, respectively. Probably, these high concentrations of VFAs had inhibited the acetoclastic-methanogenic stage [11]. Thus, despite the slight decrease in the acetic acid concentration at the end of the test, the methanogenic activity was clearly affected and, hence, the observed methane production must have come mainly from the activity of the hydrogen-utilizing methanogenic archaea. As can be seen later, in Section 3.5, there was a high fraction of organic matter as VFAs, which was not transformed into methane at the end of the tests.

The relationship between the concentrations of propionic and acetic acids ( $\mathrm{HPr} / \mathrm{HAc}$ ratio) was another very useful parameter to study the stability of the AD process. According to the literature, when the $\mathrm{HPr} / \mathrm{HAc}$ ratio exceeds 1.4, the destabilization of the process occurs [42]. However, other studies have determined that the threshold value of this relationship depends on the characteristics of the substrates used in co-digestion $[35,43]$. Figure $3 \mathrm{c}$ shows the evolution of the HPr/HAc ratio in all the mixtures. In this study, despite certain initial high values, the $\mathrm{HPr} / \mathrm{HAc}$ ratio was usually less than 2. For the mixture 50:50, values above 1.4 were recorded for 7 days, but a decrease was observed from day 20 of the test. However, for the mixture 100:0, the HPr/HAc ratio remained much lower with respect to the mixtures 25:75 and 50:50 throughout the assay. This behavior was due to the fact that the initial production of acetic acid in the mixture 100:0 was very high. Thus, although the highest concentration of propionic acid was obtained in this test, the HPr/HAc ratio remained at low level.

It can be pointed out that the microbiota coming from the inoculum was very effective to remove propionic acid. Therefore, the transitory accumulation of propionic acid could be interpreted as a decoupling between the acidogenic and acetogenic stages for a specific period.

In the literature, different threshold values of HPr have been reported as causing inhibition. Barredo and Evison [44] have indicated that concentrations of propionic acid higher than 1500-2220 mg/L could lead to inhibition. However, in the mesophilic AcoD of ESBP and PM, concentrations of HPr in the range 1099-5500 mg/L were observed and the system was not inhibited [35]. 

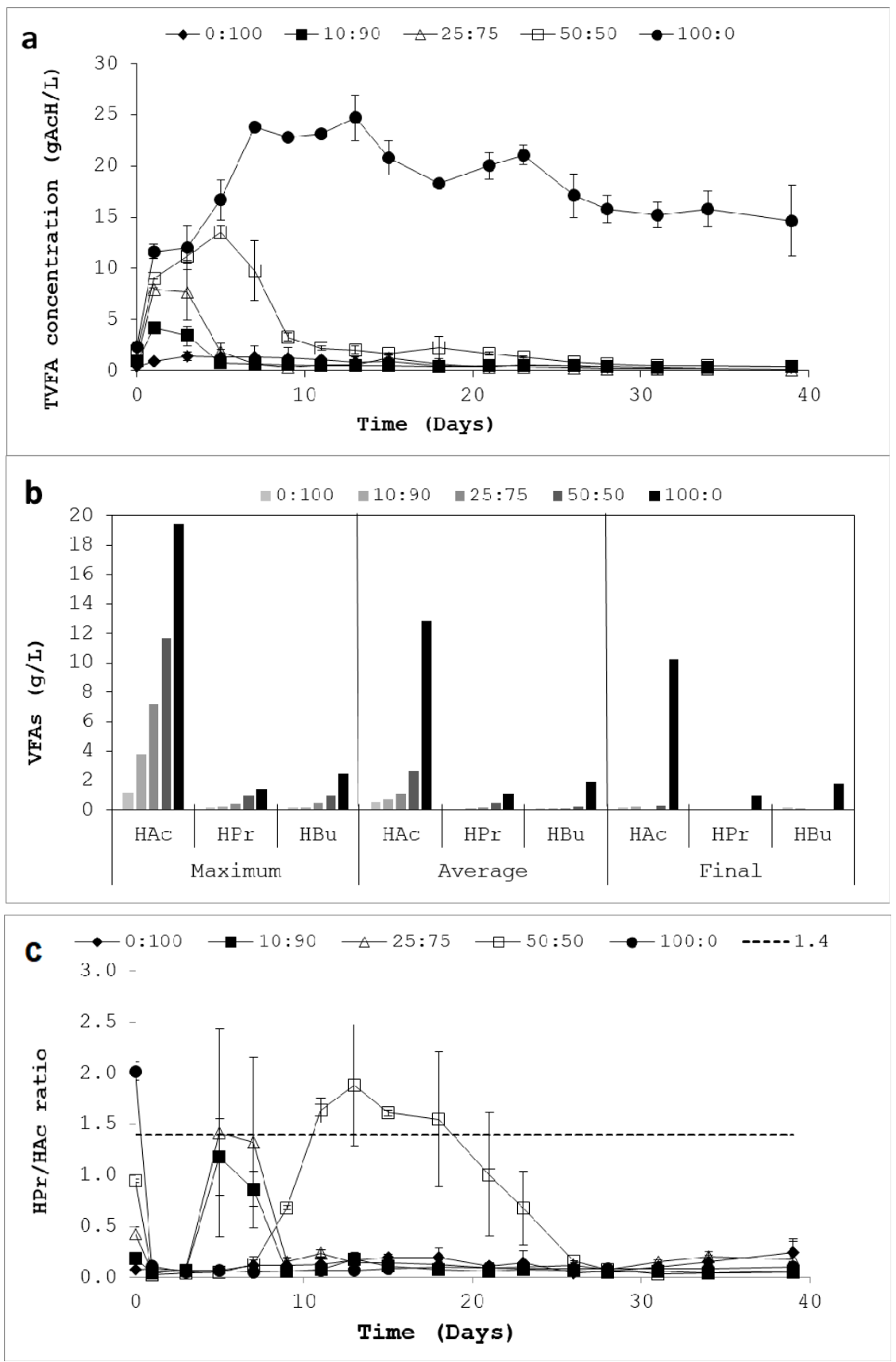

Figure 3. Evolution of total volatile fatty acidity (TVFA) concentration (a), the individual volatile fatty acids (VFAs) (b), and the ratio propionic (HPr)/ Acetic (HAc) acid (c) in all the ESBP:PM ratios.

In this work, the maximum concentrations of propionic acid detected were: $125.42 \mathrm{mg} / \mathrm{L}$, $277.02 \mathrm{mg} / \mathrm{L}, 447.75 \mathrm{mg} / \mathrm{L}, 972.88 \mathrm{mg} / \mathrm{L}$, and $1401.26 \mathrm{mg} / \mathrm{L}$ for the mixtures 0:100, 10:90, 25:75, 50:50, and 100:0, respectively. Therefore, the concentrations of propionic acid for the mixture 100:0 could not be considered as the only responsible factor for the destabilization of the process.

\subsection{Methane Production}

The reactors were maintained in operation until no significant methane production was detected. Figure 4 shows the specific methane production (SMP) obtained in all the digesters. It can be seen that the SMP was improved in all co-digestion mixtures, with respect to the individual digestion of ESBP. The following data were obtained for the different tests: $19.2 ; 108.1 ; 212.4 ; 141.4$, and $47.9 \mathrm{~mL}$ $\mathrm{CH}_{4} / \mathrm{gVS}_{\text {added }}$ for the mixtures 0:100; 10:90; 25:75; 50:50, and 100:0, respectively. 


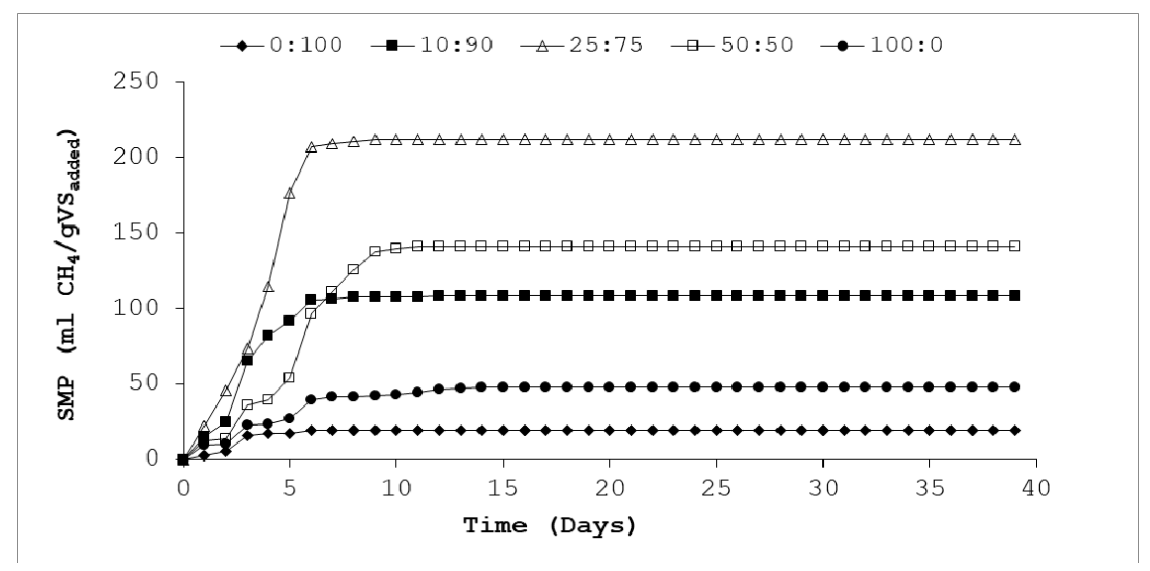

Figure 4. Specific accumulated methane production for the different mixtures tested.

In terms of methane production, the best mixture was 25:75. In fact, the reactor with the mixture 25:75 had rapidly reached the maximum SMP of $212.4 \mathrm{~mL} \mathrm{CH}_{4} / \mathrm{gVS}_{\text {added }}$ with a very short lag phase (2 days). Aboudi et al. [40] found an optimal ratio of 32:68 with an SMP of $494 \mathrm{~mL} \mathrm{CH}_{4} / \mathrm{gVS}_{\text {added }}$ at the mesophilic range. Ohuchi et al. [6] obtained an SMP of 377-422 $\mathrm{mL} \mathrm{CH}_{4} / \mathrm{gVS}_{\text {added }}$ for anaerobic co-digestion of cow manure with ensiled sugar beet tops at the proportion of $40 \%$. The maximum SMP found for the mixture 25:75 in this work was approximately 11 times higher than for the mixture 0:100 (PM alone) and 5 times higher than 100:0 (ESBP alone), highlighting the synergy of the co-digestion of both substrates.

Therefore, it could be admitted that the co-digestion of ESBP and PM in the thermophilic range showed a synergistic effect in the methane production and the rate of the organic matter degradation, with respect to the individual anaerobic digestion of PM and ESBP. The synergy observed was due to the fact that the mixture of both wastes generated more appropriate environmental conditions for the development of the process; that is, both the nutrient balance $(\mathrm{C} / \mathrm{N}$ ratio) and the available alkalinity were improved. In addition, pig manure added microorganisms from its digestive tract which could enhance the hydrolysis of the lignocellulosic material present in the ESBP. These results were in line with what has been reported by several authors studying AD of agro-industrial wastes $[45,46]$.

Nevertheless, it must be noted that the SMP obtained for the PM used in this study was clearly lower than that obtained in a previous study, conducted under mesophilic conditions [46], where a value of $468 \mathrm{~mL} / \mathrm{VS}_{\text {added }}$ was reached. Moreover, this effect seemed to extend to the assay with the ratio 10:90, due to its high PM proportion. This aspect could be due to the different characteristics of the manures used in both tests. Another possible explanation for this difference could be related to the presence of typical animal manure toxics (ammonia nitrogen, drugs, and antibiotics). The inhibition by ammonia nitrogen was especially relevant in the thermophilic anaerobic digestion [47] and several authors reported that animal manures were a reservoir of antibiotic-resistant genes, outlining that for PM, around 149 antibiotic-resistant genes were found [48-50]. However, to support this hypothesis, additional specific analytical determinations should be performed.

\subsection{Acidogenic Substrate as Carbon (ASC)}

In order to obtain a more detailed interpretation of when the process failed (see Section 2.4), the indirect parameters ASC and DAC were calculated since they allowed a better understanding of the origin of the distortions [8]. The study of the ASC parameter, which represented the hydrolyzed and solubilized organic matter that had not been degraded to VFAs, permitted to interpret the appearance of the inhibitory effects in acidogenesis stage [34]. A transitory accumulation of ASC denoted the existence of some type of limitations in acidogenesis because the hydrolysis stage was normally the rate-limiting step of the anaerobic degradation of solid wastes [32]. Figure 5 shows the evolution of these parameters in all reactors. 


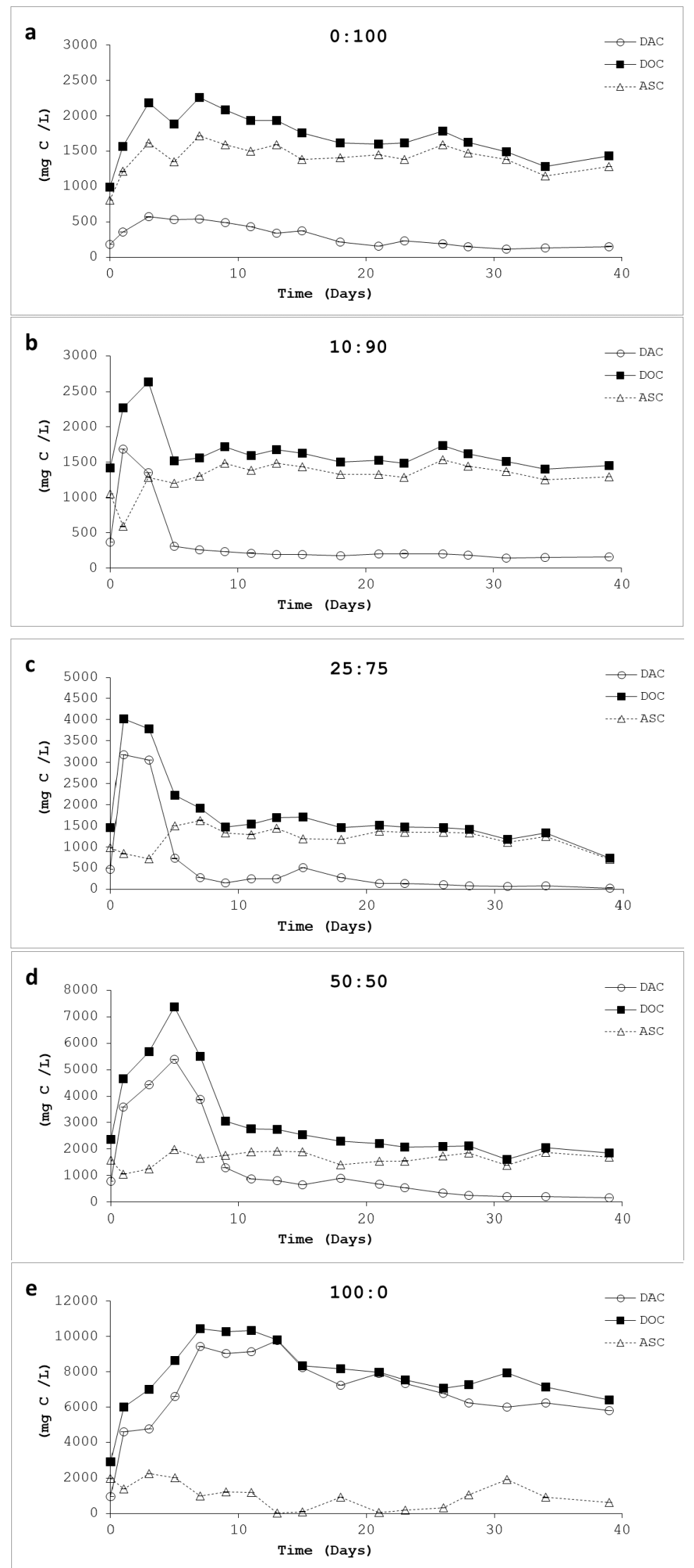

Figure 5. Evolution of dissolved organic carbon (DOC), dissolved acid carbon (DAC), and acidogenic substrate as carbon (ASC) in each reactor. (a) Reactor 0:100; (b) Reactor 10:90; (c) Reactor 25:75; (d) Reactor 50:50, and (e) Reactor 100:0. 
It could be observed that the ASC was not accumulated in any test. In fact, ASC reached rapidly the final level for this parameter, indicating that this value represented the concentration of the organic carbon that could not be transformed into VFAs. This behavior was observed for all tests, including the mixture 100:0 (ESBP alone). Moreover, the increase of organic matter added to the medium, when the ESBP proportion in the mixture increased, led to an increase in the maximum TVFA obtained. Therefore, it could be deduced that the inhibition of the acidogenic stage did not occur and that the hydrolytic and acidogenic stages were well-coupled in all reactors. However, the acidogenic and methanogenic stages were not coupled in the determined periods in each test. In these periods, the acidogenesis rate was higher than that of methanogenesis and, hence, an accumulation of VFA was observed. The decoupling periods were longer in reactors with high proportions of ESBP in the mixtures. Indeed, the decoupling period covered the entire test for the mixture 100:0 (ESBP alone), due to the inhibition of the acetoclastic metanogenic population, as a response of the excessively high level of TVFA.

\subsection{Influence of the Temperature Range}

Temperature is a key variable in all biological processes. Although it is generally admitted that thermophilic anaerobic digestion improves the kinetics and the methane yield of the process, in comparison to the mesophilic range, there are some possible drawbacks in the function of the substrate and the operational conditions. Therefore, when the hydrolytic and acidogenic stages are predominant in a thermophilic system, a significant accumulation of VFAs occurs due to the inhibition of acetoclastic methanogenic microorganisms, which are the most sensitive microorganisms to temperature [51].

As was previously pointed out in Section 3.3, a significant improvement in methane production was obtained by applying the co-digestion option with respect to the anaerobic digestion of the individual substrates. However, the calculated SMPs were markedly lower than those obtained in the mesophilic process [46].

Figure 6 depicts the DOC evolution in this study, together with data from a previous mesophilic study of Aboudi et al. [46]. Maximum values of DOC have been taken into account for this comparison, since they represent the situation of maximum unbalance between solubilization and consumption of organic matter in batch processes. At the thermophilic temperature conditions, the evolution of DOC was very similar to that previously commented on TVFA and the maximum of DOC achieved in each test was directly related to the ESBP content. In fact, and for the mixture 100:0, the removal of the dissolved organic matter (as DOC) was very low, since an important fraction remained in the medium as VFAs, mainly as acetic acid.

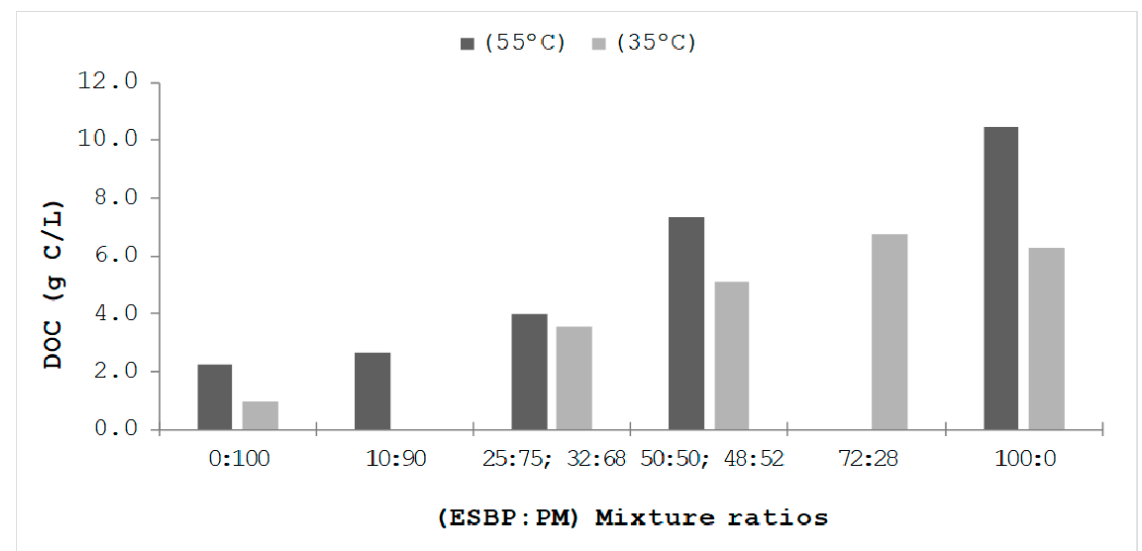

Figure 6. Maximum values of DOC in thermophilic assays (this study) and mesophilic assays [46].

Aboudi et al. [46] have found the same trend in the increase of the maximum values of DOC when the ESBP proportion in the mixture increased. However, as can be seen in Figure 6, these maximum 
values were generally lower with respect to those observed in this study. The reason is that hydrolysis rate was normally sharper in the thermophilic process than in the mesophilic one [14,15].

Likewise, the PM degradation was not complete in the reactors with a high proportion of PM, as has been discussed previously. Considering all these issues, the comparison between the mesophilic and thermophilic assays needed a new indicator, allowing the estimation of the theoretical methane that could be obtained from the non-degraded organic matter. This variable would be the percentage of the non-produced methane from ASC or VFA in the system, with respect to the total theoretical methane (non-produced and produced) that could be generated if all the organic matter was converted.

VFAs and ASC concentrations refer to the organic material which has not been converted into biogas. For this, the final levels of VFAs and the ASC were considered for the theoretical calculations. Only concentrations of the predominant VFAs (HAc, $\mathrm{HPr}$, and $\mathrm{HBu}$ ) were used. Moreover, the ASC was considered to be completely converted to VFAs in the same proportion observed at the end of the tests.

The following equations were considered for the calculations:

$$
\begin{gathered}
\mathrm{CH}_{3} \mathrm{COO}^{-}+\mathrm{H}_{2} \mathrm{O} \rightarrow \mathrm{CH}_{4}+\mathrm{HCO}_{3}^{-} \\
\mathrm{CH}_{3} \mathrm{CH}_{2} \mathrm{COO}^{-}+3 \mathrm{H}_{2} \mathrm{O} \rightarrow \mathrm{CH}_{3} \mathrm{COO}^{-}+\mathrm{HCO}_{3}^{-}+\mathrm{H}^{+}+3 \mathrm{H}_{2} \\
\mathrm{CH}_{3} \mathrm{CH}_{2} \mathrm{CH}_{2} \mathrm{COO}^{-}+2 \mathrm{H}_{2} \mathrm{O} \rightarrow 2 \mathrm{CH}_{3} \mathrm{COO}^{-}+\mathrm{H}^{+}+2 \mathrm{H}_{2} \\
\mathrm{CO}_{2}+2 \mathrm{H}_{2} \rightarrow \mathrm{CH}_{4}+2 \mathrm{H}_{2} \mathrm{O}
\end{gathered}
$$

In an efficient $\mathrm{AD}$ system, the combination between the above-mentioned equations enables the calculation of the carbon proportions converted into methane for each substrate. These carbon proportions are $1 / 2,7 / 12$, and 5/8 for acetic, propionic, and butyric acids, respectively. Table 2 shows

\begin{tabular}{|c|c|c|c|c|c|c|c|c|}
\hline Assay & Reference & $\begin{array}{l}\mathrm{CH}_{4} \text { (HAc) } \\
\text { (L/L } \mathrm{L}_{\text {reactor }} \text { ) }\end{array}$ & $\begin{array}{l}\mathrm{CH}_{4}(\mathrm{HPr}) \\
\left(\mathrm{L} / \mathrm{L}_{\text {reactor }}\right)\end{array}$ & $\begin{array}{l}\mathrm{CH}_{4}(\mathrm{HBu}) \\
\left.\text { (L/L } \mathrm{L}_{\text {reactor }}\right)\end{array}$ & $\begin{array}{l}\mathrm{CH}_{4} \text { (ASC) } \\
\text { (L/L } \mathrm{L}_{\text {reactor }} \text { ) }\end{array}$ & $\begin{array}{c}\mathrm{CH}_{4} \\
(\mathrm{VFAs}+\mathrm{ASC}) \\
(\mathrm{L})\end{array}$ & $\begin{array}{c}\mathrm{CH}_{4} \\
\text { (Produced) } \\
\text { (L) }\end{array}$ & $\begin{array}{c}\mathrm{CH}_{4} \\
\text { (Non-Produced) } \\
(\%)\end{array}$ \\
\hline $10: 90 \mathrm{~T}$ & \multirow{3}{*}{$\begin{array}{l}\text { This } \\
\text { study }\end{array}$} & 0.100 & 0.006 & 0.042 & 0.100 & 0.42 & 4.03 & 9.40 \\
\hline $25: 75 \mathrm{~T}$ & & 0.039 & 0.011 & 0.012 & 0.100 & 0.27 & 9.16 & 2.90 \\
\hline $50: 50 \mathrm{~T}$ & & 0.064 & 0.009 & 0.051 & 0.103 & 0.39 & 8.43 & 4.40 \\
\hline $32: 68 \mathrm{M}$ & \multirow{4}{*}{$\begin{array}{l}\text { Aboudi } \\
\text { et al. [44] }\end{array}$} & 0.003 & 0.000 & 0.002 & 0.100 & 0.21 & 8.48 & 2.4 \\
\hline $48: 52 \mathrm{M}$ & & 0.011 & 0.001 & 0.004 & 0.099 & 0.23 & 9.34 & 2.4 \\
\hline $72: 28 \mathrm{M}$ & & 0.041 & 0.025 & 0.003 & 0.099 & 0.34 & 10.19 & 3.2 \\
\hline 100:0M & & 0.266 & 0.200 & 0.022 & 0.107 & 5.19 & 11.04 & 32.0 \\
\hline
\end{tabular}
the obtained results of this estimation.

Table 2. Estimation of the theoretical methane from the non-converted Volatile Fatty Acids (VFAs) and Acidogenic Substrate as Carbon (ASC).

T-thermophilic; M-mesophilic. It can be observed that the methane production associated with the theoretical ASC conversion was very low and was similar in all the assays. This finding enforces the fact that the hydrolysis and acidogenesis stages have not been limited in any operational condition.

As can be observed, for all co-digestion assays, the organic matter was almost completely converted into methane, and the percentage of the non-produced methane ranged from $2.4 \%-4.4 \%$. However, a different behavior was observed for the two thermophilic reactors with high PM content, in which a noticeable fraction of the methane, associated with the non-converted ASC and VFAs $(9.4 \%$ and $32.7 \%$ in 10:90T and 0:100T, respectively), was observed. In terms of the estimated methane from ASC and VFAs, both data were similar $(0.42 \mathrm{~L})$ and the final difference was attributed to the additional organic matter provided by the ESBP in the reactor 10:90T. In addition, the differences with respect to the mesophilic tests could be attributed to the PM characteristics, as previously commented. 
The results from the reactors containing only the ESBP as the substrate have demonstrated that the methanogenesis stage was clearly affected, in both 100:0T and 100:0M reactors.

In the reactor 100:0T, the fast release of VFAs had induced a maximum level of acetic acid of $25 \mathrm{~g} / \mathrm{L}$ around day 13 (Figure 3), which had prevented a normal development of the methanogenesis, leaving a final concentration of acetic acid equivalent to $4 \mathrm{~L} \mathrm{CH}_{4} / \mathrm{L}_{\text {reactor. }}$ The estimation of the methane fraction from the non-converted ASC and VFAs was $77.1 \%$. This percentage was similar to that proposed by Smith and Mah [52], who estimated that $73 \%$ of the total methane was produced by acetoclastic methanogenesis, while the remaining $27 \%$ was produced by the hydrogen-utilizing methanogens.

However, the estimation of the methane fraction from the non-converted ASC and VFAs in the reactor $100: 0 \mathrm{M}$ was $32.0 \%$. Thus, the acetic acid was degraded in a higher proportion than in the thermophilic reactor, while the propionic acid had slightly increased with respect to the other mesophilic co-digestion tests. The different behavior of methanogenesis in both cases could be likely related to a possible accumulation of intermediate inhibitory compounds in the thermophilic reactor, such as long chain fatty acids (LCFAs) [17,53,54].

In a recent work, Aboudi et al. [11] had studied the anaerobic digestion of ESBP in a temperature phased CSTR reactors (hyperthermophilic at $65{ }^{\circ} \mathrm{C}$-mesophilic at $35{ }^{\circ} \mathrm{C}$ and thermophilic at $55{ }^{\circ} \mathrm{C}$-mesophilic at $35^{\circ} \mathrm{C}$ ). Authors reported an LCFAs accumulation in the hyperthermophilic and thermophilic reactors. Hence, palmitic acid concentrations of 140 and $210 \mathrm{mg} / \mathrm{L}$ and lignoceric acid concentrations of 80 and $125 \mathrm{mg} / \mathrm{L}$ were detected in thermophilic and hyperthermophilic reactors, respectively. The concentration of these acids was significantly reduced in the subsequent mesophilic reactors. Therefore, the inhibition of methanogenic acetoclastic archaea in the anaerobic digestion of ESBP, could be linked to the operations at high temperatures.

\section{Conclusions}

The thermophilic co-digestion of the exhausted sugar beet pulp with pig manure allowed for the achievement of an increase in the methane yield, with respect to the anaerobic digestion of ESBP, individually. The addition of PM had a beneficial effect, as it provided additional alkalinity and nitrogen and, consequently, increased the stability of the process. Moreover, the ESBP provided carbon and had contributed to a better $\mathrm{C} / \mathrm{N}$ balance in the process. Therefore, the mixture of both wastes had a synergistic effect on the process. Thus, the ratio 25:75 (ESBP:PM) was the best proportion tested with a specific methane production of $212 \mathrm{~mL} / \mathrm{VS}_{\text {added }}$.

Despite the thermophilic range being normally considered favorable for increasing the process rate and product yield, the comparison of the results obtained with previous mesophilic studies from the literature indicated that the temperature had a detrimental effect on the process. Thus, in this study, the population of methanogenic acetoclastic archaea seems to have been affected and the methane production would have been mostly generated by the pathway of the hydrogen-utilizing microorganisms.

Author Contributions: The authors contribute equally to this work.

Funding: This research was supported by the projects CTM2013-43938-R and CTM2016-79071-R (Spanish Ministry of Economy, Industry and Competitiveness) and financed by the Spanish State Research Agency ("Agencia Estatal de Investigación"-AEI), and by the European Regional Development Fund (ERDF). The Authors also acknowledge the University of Cádiz (Spain) for the Scholarship UCA-2014-043/PU/EPIF-FPI-CT/CP, the Agri-food Campus of International Excellence (Ceia3) and the Azucarera (an AB Sugar Company) for the supply of the samples of exhausted sugar beet pulp.

Conflicts of Interest: The authors declare no conflict of interest.

\section{References}

1. Anwar, Z.; Gulfraz, M.; Irshad, M. Agro-industrial lignocellulosic biomass a key to unlock the future bio-energy: A brief review. J. Radiat. Res. Appl. Sci. 2014, 7, 163-173. [CrossRef] 
2. Singh, R.; Krishna, B.B.; Mishra, G.; Kumar, J.; Bhaskar, T. Strategies for selection of thermo-chemical processes for the valorisation of biomass. Renew. Energy 2016, 98, 226-237. [CrossRef]

3. Hutnan, M.; Drtil, M.; Mrafkova, L. Anaerobic biodegradation of sugar beet pulp. Biodegradation 2000, 11, 203-211. [CrossRef]

4. Aboudi, K.; Álvarez-Gallego, C.J.; Romero-García, L.I. Biomethanization of sugar beet byproduct by semi-continuous single digestion and co-digestion with cow manure. Bioresour. Technol. 2016, 200, 311-319. [CrossRef]

5. Montañés, R.; Solera, R.; Pérez, M. Anaerobic co-digestion of sewage sludge and sugar beet pulp lixiviation in batch reactors: effect of temperature. Bioresour. Technol. 2015, 180, 177-184. [CrossRef]

6. Ohuchi, Y.; Ying, C.; Lateef, S.A.; Ihara, I.; Iwasaki, M.; Inoue, R.; Umetsu, K. Anaerobic co-digestion of sugar beet tops silage and dairy cow manure under thermophilic condition. J. Mater. Cycles Waste Manag. 2015, 17, 540-546. [CrossRef]

7. Ward, A.J.; Hobbs, P.J.; Holliman, P.J.; Jones, D.L. Optimisation of the anaerobic digestion of agricultural resources. Bioresour. Technol. 2008, 99, 7928-7940. [CrossRef]

8. Fdez-Güelfo, L.A.; Álvarez-Gallego, C.; Sales, D.; Romero, L.I. New indirect parameters for interpreting a destabilization episode in an anaerobic reactor. Chem. Eng. J. 2012, 180, 32-38. [CrossRef]

9. Velásquez Piñas, J.A.; Venturini, O.J.; Silva Lora, E.E.; Calle Roalcaba, O.D. Technical assessment of mono-digestion and co-digestion systems for the production of biogas from anaerobic digestion in Brazil. Renew. Energy 2018, 117, 447-458. [CrossRef]

10. Salsabil, M.R.; Laurent, J.; Casellas, M.; Dagot, C. Techno-economic evaluation of thermal treatment, ozonation and sonication for the reduction of wastewater biomass volume before aerobic or anaerobic digestion. J. Hazard. Mater. 2010, 174, 323-333. [CrossRef]

11. Aboudi, K.; Gómez-Quiroga, X.; Álvarez-Gallego, C.J.; Quiroga-Alonso, J.M.; Romero-García, L.I. Effect of Temperature on Biohydrogen and Biomethane Productions by Anaerobic Digestion of Sugar Beet by-Products. Int. J. Environ. Sci. Dev. 2018, 8, 762-766. [CrossRef]

12. Zahedi, S. Energy efficiency: Importance of indigenous microorganisms contained in the municipal solid wastes. Waste Manag. 2018, 78, 763-769. [CrossRef]

13. Zahedi, S.; Dahunsi, S.O.; Perez, M.; Solera, R. Assessment of chemical inhibitor addition to improve the gas production from biowaste. Waste Biomass Valoriz. 2017, 10, 1091-1099. [CrossRef]

14. Fernández-Rodríguez, J.; Pérez, M.; Romero, L.I. Comparison of mesophilic and thermophilic dry anaerobic digestion of OFMSW: Kinetic analysis. Chem. Eng. J. 2013, 232, 59-64. [CrossRef]

15. Fernández-Rodríguez, J.; Preze, M.; Romero, L.I. Bio-methanization of organic fraction from municipal solid waste: Temperature effects. Polish J. Chem. Technol. 2013, 15, 99-106. [CrossRef]

16. Sawatdeenarunat, C.; Surendra, K.C.; Takara, D.; Oechsner, H.; Khanal, S.K. Anaerobic digestion of lignocellulosic biomass: Challenges and opportunities. Bioresour. Technol. 2015, 178, 178-186. [CrossRef]

17. Palatsi, J.; Illa, J.; Prenafeta-Boldú, F.X.; Laureni, M.; Fernandez, B.; Angelidaki, I.; Flotats, X. Long-chain fatty acids inhibition and adaptation process in anaerobic thermophilic digestion: Batch tests, microbial community structure and mathematical modelling. Bioresour. Technol. 2010, 101, 2243-2251. [CrossRef]

18. Mata-Alvarez, J.; Dosta, J.; Romero-Güiza, M.S.S.; Fonoll, X.; Peces, M.; Astals, S. A critical review on anaerobic co-digestion achievements between 2010 and 2013. Renew. Sustain. Energy Rev. 2014, 36, 412-427. [CrossRef]

19. Neshat, S.A.; Mohammadi, M.; Najafpour, G.D.; Lahijani, P. Anaerobic co-digestion of animal manures and lignocellulosic residues as a potent approach for sustainable biogas production. Renew. Sustain. Energy Rev. 2017, 79, 308-322. [CrossRef]

20. Sanaei-Moghadam, A.; Abbaspour-Fard, M.H.; Aghel, H.; Aghkhani, M.H.; Abedini-Torghabeh, J. Enhancement of Biogas Production by Co-digestion of Potato Pulp with Cow Manure in a CSTR System. Appl. Biochem. Biotechnol. 2014, 173, 1858-1869. [CrossRef]

21. Rodriguez-Verde, I.; Regueiro, L.; Carballa, M.; Hospido, A.; Lema, J.M. Assessing anaerobic co-digestion of pig manure with agroindustrial wastes: the link between environmental impacts and operational parameters. Sci. Total Environ. 2014, 497-498, 475-483. [CrossRef]

22. Aboudi, K.; Álvarez-Gallego, C.J.; Romero-García, L.I. Semi-continuous anaerobic co-digestion of sugar beet byproduct and pig manure: Effect of the organic loading rate (OLR) on process performance. Bioresour. Technol. 2015, 194, 283-290. [CrossRef] 
23. Fang, C.; Boe, K.; Angelidaki, I. Anaerobic co-digestion of by-products from sugar production with cow manure. Water Res. 2011, 45, 3473-3480. [CrossRef]

24. Umetsu, K.; Yamazaki, S.; Kishimoto, T.; Takahashi, J.; Shibata, Y.; Zhang, C.; Misaki, T.; Hamamoto, O.; Ihara, I.; Komiyama, M. Anaerobic co-digestion of dairy manure and sugar beets. Int. Congr. Ser. 2006, 1293, 307-310. [CrossRef]

25. Wu, X.; Yao, W.; Zhu, J.; Miller, C. Biogas and $\mathrm{CH}(4)$ productivity by co-digesting swine manure with three crop residues as an external carbon source. Bioresour. Technol. 2010, 101, 4042-4047. [CrossRef]

26. Aboudi, K.; Álvarez-Gallego, C.J.; Romero-García, L.I. Influence of total solids concentration on the anaerobic co-digestion of sugar beet by-products and livestock manures. Sci. Total Environ. 2017, 586, 438-445. [CrossRef]

27. Ge, X.; Xu, F.; Li, Y. Solid-state anaerobic digestion of lignocellulosic biomass: Recent progress and perspectives. Bioresour. Technol. 2016, 205, 239-249. [CrossRef]

28. Chandra, R.; Takeuchi, H.; Hasegawa, T. Methane production from lignocellulosic agricultural crop wastes: A review in context to second generation of biofuel production. Renew. Sustain. Energy Rev. 2012, 16, 1462-1476. [CrossRef]

29. Liotta, F.; d'Antonio, G.; Esposito, G.; Fabbricino, M.; Frunzo, L.; van Hullebusch, E.D.; Lens, P.N.L.; Pirozzi, F. Effect of moisture on disintegration kinetics during anaerobic digestion of complex organic substrates. Waste Manag. Res. 2014, 32, 40-48. [CrossRef]

30. Holliger, C.; Alves, M.; Andrade, D.; Angelidaki, I.; Astals, S.; Baier, U.; Bougrier, C.; Buffière, P.; Carballa, M.; de Wilde, V.; et al. Towards a standardization of biomethane potential tests. Water Sci. Technol. 2016, 74, 2515-2522. [CrossRef]

31. APHA-AWWA-WPCF. Standard Methods for the Examination of Water and Wastewater, 20th ed.; American Public Health Association: Washington, DC, USA, 2005.

32. Álvarez-Gallego, C.J. Testing Different Procedures for the Start-Up of a Dry Anaerobic Co-Digestion Process of OFMSW and Sewage Sludge at Thermophilic Range, University of Cadiz. 2005. Available online: https://dialnet.unirioja.es/servlet/tesis?codigo=52224 (accessed on 30 September 2018).

33. Van Soest, P.J.; Robertson, J.B.; Lewis, B.A. Methods for Dietary Fiber, Neutral Detergent Fiber, and Nonstarch Polysaccharides in Relation to Animal Nutrition. J. Dairy Sci. 1991, 74, 3583-3597. [CrossRef]

34. Angeriz-Campoy, R.; Fdez-Güelfo, L.A.; Tyagi, V.K.; Álvarez-Gallego, C.J.; Romero-García, L.I. New criteria to determine the destabilization of the acidogenic anaerobic co-digestion of organic fraction of municipal solid waste (OFMSW) with mixed sludge (MS). Bioresour. Technol. 2018, 248, 174-179. [CrossRef]

35. Aboudi, K.; Álvarez-Gallego, C.J.; Romero-García, L.I. Evaluation of methane generation and process stability from anaerobic co-digestion of sugar beet by-product and cow manure. J. Biosci. Bioeng. 2016, 121, 566-572. [CrossRef]

36. Wang, M.; Zhou, J.; Yuan, Y.-X.; Dai, Y.-M.; Li, D.; Li, Z.-D.; Liu, X.-F.; Zhang, X.-Y.; Yan, Z.-Y. Methane production characteristics and microbial community dynamics of mono-digestion and co-digestion using corn stalk and pig manure. Int. J. Hydrogen Energy 2017, 42, 4893-4901. [CrossRef]

37. Guwy, A.J.; Hawkes, F.R.; Wilcox, S.J.; Hawkes, D.L. Neural network and on-off control of bicarbonate alkalinity in a fluidised-bed anaerobic digester. Water Res. 1997, 31, 2019-2025. [CrossRef]

38. Angelidaki, I.; Ahring, B.K. Thermophilic anaerobic digestion of livestock waste: the effect of ammonia. Appl. Microbiol. Biotechnol. 1993, 38, 560-564. [CrossRef]

39. Callaghan, F.J.; Wase, D.A.J.; Thayanithy, K.; Forster, C.F. Continuous co-digestion of cattle slurry with fruit and vegetable wastes and chicken manure. Biomass Bioenergy 2002, 22, 71-77. [CrossRef]

40. Switzenbaum, M.S.; Giraldo-Gomez, E.; Hickeyt, R.F. Monitoring of the anaerobic methane fermentation process. Enzyme Microb. Technol. 1990, 12, 722-730. [CrossRef]

41. Zickefoose, C.; Hayes, R.B.J.; Bryant, J.O. Anaerobic Sludge Digestion: Operations Manual. EPA 430=9-76-001; National Technical Information Service, Ed.; United States Environmental Protection Agency: Washington, DC, USA, 1976.

42. Hill, D.T.; Cobb, S.A.; Bolte, J.P. Using Volatile Fatty Acid Relationships to Predict Anaerobic Digester Failure. Trans. ASAE 1987, 30, 496. [CrossRef]

43. Pullammanappallil, P.C.; Chynoweth, D.P.; Lyberatos, G.; Svoronos, S.A. Stable performance of anaerobic digestion in the presence of a high concentration of propionic acid. Bioresour. Technol. 2001, 78, 165-169. [CrossRef] 
44. Barredo, M.S.; Evison, L.M. Effect of propionate toxicity on methanogen-enriched sludge, Methanobrevibacter smithii, and Methanospirillum hungatii at different pH values. Appl. Environ. Microbiol. 1991, 57, 1764-1769. [PubMed]

45. Wang, Y.; Li, G.; Chi, M.; Sun, Y.; Zhang, J.; Jiang, S.; Cui, Z. Effects of co-digestion of cucumber residues to corn stover and pig manure ratio on methane production in solid state anaerobic digestion. Bioresour. Technol. 2018, 250, 328-336. [CrossRef] [PubMed]

46. Aboudi, K.; Álvarez-Gallego, C.J.; Romero-García, L.I. Improvement of Exhausted Sugar Beet Cossettes Anaerobic Digestion Process by Co-Digestion with Pig Manure. Energy Fuels 2015, 29, 754-762.

47. Yang, Z.; Wang, W.; He, Y.; Zhang, R.; Liu, G. Effect of ammonia on methane production, methanogenesis pathway, microbial community and reactor performance under mesophilic and thermophilic conditions. Renew. Energy 2018, 125, 915-925. [CrossRef]

48. Selvam, A.; Xu, D.; Zhao, Z. Fate of tetracycline, sulfonamide and fluoroquinolone resistance genes and the changes in bacterial diversity during composting of swine manure. Bioresour. Technol. 2012, 126, 383-390. [CrossRef]

49. Zhu, Y.-G.; Johnson, T.A.; Su, J.-Q.; Qiao, M.; Guo, G.-X.; Stedtfeld, R.D.; Hashsham, S.A.; Tiedje, J.M. Diverse and abundant antibiotic resistance genes in Chinese swine farms. Proc. Natl. Acad. Sci. USA 2013, 110, 3435-3440. [CrossRef]

50. Zhang, J.; Sui, Q.; Zhong, H.; Meng, X.; Wang, Z.; Wang, Y.; Wei, Y. Impacts of zero valent iron, natural zeolite and Dnase on the fate of antibiotic resistance genes during thermophilic and mesophilic anaerobic digestion of swine manure. Bioresour. Technol. 2018, 258, 135-141. [CrossRef]

51. Montañés Alonso, R.; Solera del Río, R.; Pérez García, M. Thermophilic and mesophilic temperature phase anaerobic co-digestion (TPAcD) compared with single-stage co-digestion of sewage sludge and sugar beet pulp lixiviation. Biomass Bioenergy 2016, 93, 107-115. [CrossRef]

52. Smith, P.H.; Mah, R.A. Kinetics of acetate metabolism during sludge digestion. Appl. Microbiol. 1966, 14, 368-371.

53. Chan, P.C.; de Toledo, R.A.; Shim, H. Anaerobic co-digestion of food waste and domestic wastewater. Effect of intermittent feeding on short and long chain fatty acids accumulation. Renew. Energy 2018, 124, 129-135. [CrossRef]

54. Rasit, N.; Idris, A.; Harun, R.; Wan Ab Karim Ghani, W.A. Effects of lipid inhibition on biogas production of anaerobic digestion from oily effluents and sludges: An overview. Renew. Sustain. Energy Rev. 2015, 45, 351-358. [CrossRef] 